\title{
Developmental Expression of Endothelial Nitric Oxide Synthase (eNOS) in the Rat Liver
}

\author{
MICHAEL J. NOWICKI, DONGPING SHI, ZHENGWEI CAI, PHYLLIS R. BISHOP, AND \\ WARREN L. MAY \\ Divisions of Pediatric Gastroenterology [M.J.N., D.S., P.R.B.], Neonatology [Z.C.], and Preventive \\ Medicine [W.L.M.], University of Mississippi Medical Center, Jackson, Mississippi, 39216, U.S.A.
}

\begin{abstract}
ABSTR
Transition from fetal to postnatal life requires significant
changes in cardiac, pulmonary, and hepatic blood flow. As such,
there must be changes in vascular control in these vascular
systems. Vascular resistance, a major contributor to blood flow,
is mediated in the ductus arteriosus and pulmonary vasculature
by endothelial nitric oxide synthase (eNOS). This study was
conducted to determine the ontogeny of hepatic eNOS expres-
sion and activity. Additionally, the expression and activity of
inducible nitric oxide synthase (iNOS) was measured to deter-
mine whether perinatal hypoxia resulted in detectable levels.
NOS mRNA and proteins were determined by reverse transcrip-
tion PCR assay and semiquantitative Western blot analysis,
respectively. NOS activity was measured by the formation of
[ $\left.{ }^{14} \mathrm{C}\right]$-citrulline from $\left[{ }^{14} \mathrm{C}\right]$-arginine. Localization of eNOS
within the liver was determined by immunohistochemistry.
eNOS mRNA was detectable at low levels at 18 -d gestation and
increased after birth, reaching a maximum level (4.5-fold in-
crease) at $20 \mathrm{~d}$ of life. Parallel patterns for eNOS protein and
\end{abstract}
NO is a short-lived free radical that influences physiologic processes in essentially every organ and tissue. Some of the roles of NO include neuromodulator, prevention of clotting, mediation of bactericidal and tumoricidal activity of macrophages, and regulation of blood pressure. NO is enzymatically synthesized from L-arginine by three known NOS isoforms: constitutively expressed eNOS (or NOS-3), nNOS (or NOS-1), iNOS (or NOS-2) (1-3). NO production by eNOS is primarily regulated by fluctuations in intracellular calcium levels. In the liver under normal conditions, only eNOS is present, produced by the sinusoidal endothelial cells $(4,5)$. The resulting low level of NO production is a major contributor of the basal vascular tone in the normal liver $(4,5)$.

Received October 18, 2002; accepted June 19, 2003.

Correspondence: Michael J. Nowicki, M.D., Division of Pediatric Gastroenterology and Nutrition, Blair E. Batson Children's Hospital, University of Mississippi Medical Center, 2500 North State Street, Jackson, MS 39216, U.S.A.; e-mail: mnowicki@ped.umsmed.edu

DOI: 10.1203/01.PDR.0000086904.52847.2A activity were seen, with 6.9-fold and 16.1-fold increases, respectively. In the prenatal rat, eNOS was localized to areas of extramedullary hematopoiesis, with little signal in the sinusoids. Postnatally, there was a decrease in staining in the hematopoietic cells and a gradual increase in the staining of the endothelium of the sinusoids and central veins. iNOS mRNA and protein could not be detected at any age. eNOS expression and activity are developmentally regulated, increasing after birth coincident with an initial relative hypoxia and an increase in shear forces upon closure of the ductus venosus. (Pediatr Res 54: 732-738, 2003)
NO, nitric oxide
Abbreviations
NOS, nitric oxide synthase
eNOS, endothelial nitric oxide synthase
iNOS, inducible nitric oxide synthase
nNOS, neuronal nitric oxide synthase

eNOS plays a role in control of vascular tone in most vascular beds (6). eNOS participates in the control of vascular tone during the transition from fetal circulation to postnatal circulation in the ductus arteriosus (7) and lung (8). The role of eNOS in control of the ductus arteriosus is age dependent. The effects of eNOS are more pronounced in determining vascular tone of the ductus arteriosus in the preterm animal than in the near-term or adult animal $(7,9)$. During the transition period, blood flow to the lungs is increased by a number of factors, including closure of the ductus arteriosus and dilation of the pulmonary vasculature. The latter is under the control of eNOS. Expression of eNOS in the lung is highest at the time of birth, possibly serving to optimize the capacity for pulmonary vasodilation during transition $(5,8)$. Hepatic blood flow also changes significantly postnatally. Fetal hepatic blood flow derives from the umbilical vein $(75 \%)$, portal vein $(15-20 \%)$, and hepatic artery (5-10\%), with $50 \%$ of the umbilical vein blood flow bypassing the liver via the ductus venosus. After birth, the portal vein (67-75\%) and the hepatic artery (25$33 \%$ ) supply hepatic blood flow. In the immediate postnatal 
period, the percentage oxygen saturation $\left(\% \mathrm{O}_{2}\right.$ sat $)$ of the hepatic artery increases, however, hepatic artery flow does not increase. In contrast, portal vein flow increases 3 -fold after birth, but up to $40 \%$ continues to be shunted through the ductus venosus $(10,11)$. Complete closure of the ductus venosus may not occur for several days. Thus, in the immediate postnatal period there is a decrease in oxygen delivery to the liver. As the ductus venosus closes, there is increased oxygen delivery to the liver, as well as increased shear forces in the hepatic sinusoids. Previous research has shown that expression of eNOS mRNA in the liver is up-regulated both by hypoxia (12) and increased shear forces (5).

To date, the ontogeny of hepatic eNOS has not been studied. We propose that there are age-related differences in the expression of hepatic eNOS in the developing rat, reflecting changes in oxygen delivery and shear forces as they pertain to transition from fetal to postnatal circulation. The aim of this study was to determine the pattern of the eNOS expression and activity in the liver of the developing rat.

\section{MATERIAL AND METHODS}

Chemicals. Unless otherwise stated, all chemicals used in this study were purchased from Sigma Chemical Co. (St. Louis, MO, U.S.A.). L- $\left[{ }^{14} \mathrm{C}\right]$-arginine $(0.1 \mathrm{mCi} / \mathrm{mL})$ was obtained from American Radiolabeled Chemicals (St. Louis, MO, U.S.A. $) . \alpha-\left[{ }^{32} \mathrm{P}\right]$-dATP $(10 \mathrm{mCi} / \mathrm{mL}, 3000 \mathrm{Ci} / \mathrm{mmol})$ was purchased from Amersham Health (Arlington Heights, IL, U.S.A.). Oligonucleotide primers for detection of individual NOS isoform mRNA were synthesized by DNA International, Inc. (Lake Oswego, OR, U.S.A.).

Animal care and collection of tissue. Pregnant Sprague Dawley rats were obtained at $14 \mathrm{~d}$ of gestation $($ term $=22 \mathrm{~d}$ ) and kept in plastic cages with free access to food and water with alternating 12-h periods of light and darkness. In experiments requiring fetal tissue, the dam was killed by $\mathrm{CO}_{2}$ narcosis and cervical dislocation, followed by delivery of fetuses by cesarean section. In experiments requiring neonatal tissue, pups were kept with the mother with free access to breast-feeding before weaning, and standard rat chow and water post weaning. At selected ages, pups were killed by $\mathrm{CO}_{2}$ narcosis and cervical dislocation. The time points were gestational ages of $18 \mathrm{~d}$ and $20 \mathrm{~d}$, and postnatal ages of day of birth, $1 \mathrm{~d}, 5 \mathrm{~d}$ and $20 \mathrm{~d}$. Adult, male Sprague Dawley rats (200-250 g) were used as the time point for adults, in an effort to avoid any potential effect of estrous on expression of NOS. The care and sacrifice of these animals was as described for the pregnant rats. The study was approved by the Institutional Animal Care and Use Committee at the University of Mississippi Medical Center.

Measurement of eNOS and iNOS mRNA. Total RNA was extracted from liver using TRIzol Reagent (Invitrogen, Carlsbad, CA, U.S.A.), and $1.5 \mu \mathrm{g}$ of total RNA was reverse transcribed into cDNA using Reverse Transcription System (Promega, Madison, WI, U.S.A.), using random hexamer as primers. The reaction was carried out at room temperature for $10 \mathrm{~min}$ and at $42^{\circ} \mathrm{C}$ for $60 \mathrm{~min}$, followed by termination at $95^{\circ} \mathrm{C}$ for $5 \mathrm{~min}$ and ice for $5 \mathrm{~min}$. The resulting cDNA was stored at $-70^{\circ} \mathrm{C}$ until the time of amplification.

Specific cDNA were amplified by PCR in the presence of Taq DNA polymerase and oligonucleotide primer pairs designed for targeting eNOS and iNOS cDNA. $\alpha-\left[{ }^{32} \mathrm{P}\right]$-dATP was used for labeling the amplified cDNA. The reaction was performed in a final volume of $50 \mu \mathrm{L}$, consisting of $50 \mathrm{mM}$ $\mathrm{KCL}, 10 \mathrm{mM}$ Tris-Cl, $1.5 \mathrm{mM} \mathrm{MgCl}, 0.2 \mathrm{mM}$ dNTP, $1 \mu \mathrm{Ci}$ $\alpha-\left[{ }^{32} \mathrm{P}\right]$-dATP, 1 unit Taq DNA polymerase, $0.5 \mu \mathrm{M}$ each primer, and $2 \mu \mathrm{L}$ cDNA. The PCR reaction condition was 3 min at $94^{\circ} \mathrm{C}, 29$ cycles at $94^{\circ} \mathrm{C}$ for $30 \mathrm{~s}, 55^{\circ} \mathrm{C}$ for $40 \mathrm{~s}, 72^{\circ} \mathrm{C}$ for $1 \mathrm{~min}$, and then $72^{\circ} \mathrm{C}$ for $10 \mathrm{~min}$, followed by $4^{\circ} \mathrm{C}$.

The sequences of the primer pairs for eNOS and iNOS are as follows $(13,14)$ :

eNOS:

5'-TCC AGT AAC ACA GAC AGT GAC-3' (sense)

5'-CAG GAA GTA AGT GAG AGC-3' (anti-sense)

iNOS:

5'-CTC ACT GGG ACT GCA CAG AA-3' (sense)

5'-TGT TGA AGG GTG TCG TGA AA-3' (anti-sense)

The size of the amplified DNA fragments for eNOS and iNOS are $693 \mathrm{bp}$ and $127 \mathrm{bp}$, respectively.

PCR products were subjected to a 5\% PAGE. To insure that equal amounts of reverse-transcribed cDNA were applied to the PCR reaction, the primer pairs of $\beta$-actin (CLONTECH, Palo Alto, CA, U.S.A.) were included in the PCR reaction as a reference (764 bp). The gels were first stained with ethidium bromide, photographed, and then exposed to Kodak BIOMAX MS film. A 100-bp DNA ladder marker was used to identity the molecular weight of the targeted DNA. The film was scanned and analyzed with a densitometer and the ImageQuant software (Molecular Dynamics, Sunnyvale, CA, U.S.A.). The ratio of the intensity of the eNOS band to that of $\beta$-actin was used to semiquantitatively compare NOS expression between groups (15). To insure that the reverse transcription (RT)-PCR reaction was not run to saturation, $\mathrm{PCR}$ was performed over a range of cycles for both eNOS and $\beta$-actin. The RT-PCR reaction was performed at 29 cycles, which was in the linear region of the cycles.

Western blotting for eNOS and iNOS. NOS protein level was determined by Western blot analysis. Supernatant samples collected from the NOS activity assay were boiled with loading buffer for $5 \mathrm{~min}$ and separated by 7.5\% SDS-PAGE, then transferred to nitrocellulose membranes using a Bio-Rad Electroblotter (Bio-Rad, Hercules, CA, U.S.A.). Monoclonal mouse anti-eNOS antibody (1:1000) and anti-iNOS (1:500) (Transduction Laboratories, Lexington, KY, U.S.A.) were used to detect NOS isoforms in the liver using the Enhanced Chemiluminescence System (Amersham Health). For semiquantitative comparison of the different age groups, samples were compared with $\beta$-tubulin. Monoclonal anti- $\beta$-tubulin antibody 3F3-G2 was a kind gift provided by Dr. J.L. Lessard, University of Cincinnati. Densitometric quantification of Western blot signal intensity of autoradiograms was performed using Molecular Analyst Software (Bio-Rad). The molecular weights for eNOS, iNOS, and $\beta$-tubulin are $140 \mathrm{kD}, 130 \mathrm{kD}$, and $110 \mathrm{kD}$, respectively. 
Measurement of eNOS and iNOS activity. NOS activity, estimated by formation of $\left[{ }^{14} \mathrm{C}\right]$-citrulline from $\left[{ }^{14} \mathrm{C}\right]$-arginine, was determined according to the method of Bredt and Snyder (16), with modifications. Briefly, liver was homogenized in a 1:3 weight:volume ice-cold lysis buffer containing $50 \mathrm{mM}$ HEPES ( $\mathrm{pH}$ 7.4), $1 \mathrm{mM}$ EDTA, $0.1 \mathrm{mg} / \mathrm{mL}$ aprotinin, 0.1 $\mathrm{mg} / \mathrm{mL}$ leupeptin, $0.1 \mathrm{mM}$ pepstatin $\mathrm{A}, 1 \mathrm{mM}$ phenanthroline, and $1 \mathrm{mM}$ PMSF. The homogenate was centrifuged at 20,000 $\times g$ for 30 min at $4^{\circ} \mathrm{C}$ and NOS activity was measured in the supernatant within $2 \mathrm{~h}$ of preparation. Twenty-five microliters of supernatant, $200 \mu \mathrm{L}$ of reaction buffer $(50 \mathrm{mM}$ Tris-Cl, $\mathrm{pH}$ 7.4, $1 \mathrm{mM}$ citrulline, $50 \mathrm{mM}$ valine, $10 \mu \mathrm{M}$ FAD, $1 \mathrm{mM}$ $\mathrm{NADPH}, 100 \mu \mathrm{M}$ de-gassed $\mathrm{BH}_{4}, 1 \mathrm{mM} \mathrm{CaCl}$, and $300 \mathrm{nM}$ calmodulin), and $25 \mu \mathrm{L}$ of $\left[{ }^{14} \mathrm{C}\right]$-arginine $(0.01 \mu \mathrm{Ci})$ in 180 $\mu \mathrm{M}$ nonradiolabeled $\mathrm{L}$-arginine were mixed and incubated for $30 \mathrm{~min}$ at $37^{\circ} \mathrm{C}$. The reaction was terminated by the addition of ice-cold stop buffer containing $20 \mathrm{mM}$ HEPES and $2 \mathrm{mM}$ EDTA, pH 5.5. Incubation was also performed with $4 \mathrm{mM}$ EGTA instead of $\mathrm{CaCl}_{2}$ and calmodulin for $\mathrm{Ca}^{2+}$-independent NOS activity. Duplicate samples were run in the presence and absence of $1 \mathrm{mM} \mathrm{N}^{\mathrm{G}}$-nitro-L-arginine methyl ester (L-NAME) for all samples to assure that the measured radioactivity represented NOS activity. $\left[{ }^{14} \mathrm{C}\right]$-citrulline in each sample was separated from the mixture by ion-exchange chromatography using Dowex 50W/50X-400 (sodium form) column. The eluent was collected and mixed with $10 \mathrm{~mL}$ of scintillation cocktail for radioactivity quantitation by liquid scintillation spectrometry. The results were expressed as picomoles citrulline per microgram protein per minute. The protein content of each sample was determined by the Bradford method with BSA as the standard.

Immunohistochemistry for hepatic eNOS.. Sections of liver tissue were immunostained with eNOS antibody using an $\mathrm{ABC}$ kit from Vector Laboratories (Burlingame, CA, U.S.A.) according to the manufacturer's recommendations. Briefly, $3-\mu \mathrm{L}$ thick slices of formalin-fixed, paraffin-embedded liver were mounted on slides. The slides were deparaffinized, followed by suppression of endogenous peroxidase activity by immersion in methanol containing $2 \% \mathrm{H}_{2} \mathrm{O}_{2}$ for $30 \mathrm{~min}$. Antigen retrieval was achieved by heating in $0.01 \mathrm{M}$ citric acid, $\mathrm{pH} 6.0$, for 20 min in a Handy Steamer (Black \& Decker, Model HS 800). Nonspecific binding was blocked with $10 \%$ horse serum in PBS at room temperature for $1 \mathrm{~h}$. The sections were washed in PBS with $0.05 \%$ Tween- 20 thrice for 2 min each time, followed by incubation overnight at $4{ }^{\circ} \mathrm{C}$ with mouse anti-eNOS antibody (1:50) in PBS containing $4 \%$ horse serum. The sections were washed in PBS twice for 2 min each time, followed by incubation for $1 \mathrm{~h}$ at room temperature with biotinylated goat anti-mouse $\operatorname{IgG}(1: 200)$ in PBS containing $1.5 \%$ horse serum. Next, the slides were incubated with avidin-biotinperoxidase conjugate for $30 \mathrm{~min}$ at room temperature; the colored reaction product was developed by incubation for 7 min with $0.05 \%$ diaminobenzidine in $0.01 \% \mathrm{H}_{2} \mathrm{O}_{2}$ in PBS. The slides were counterstained with hematoxylin. Negative controls were carried out under the same conditions using mouse IgG instead of eNOS antibody.

Statistical methods. We used a repeated measures ANOVA to examine differences in the means for the seven time inter- vals. Because of suspected heterogeneity of the variances, we transformed the data to a natural logarithm scale to perform the ANOVA. A global test aimed at assessing significant differences in the responses over time was considered significant if $p<0.05$. After a significant global test, pair-wise differences were assessed using a Bonferroni approach. In addition, a test for linear trend was reported as an indication of general increase in response over time.

\section{RESULTS}

Expression of eNOS $\boldsymbol{m} \boldsymbol{R} N A$. We first performed a RT-PCR reaction for eNOS, iNOS, and $\beta$-actin at increasing numbers of cycles to insure that the reaction had not reached saturation. PCR products were seen for eNOS and $\beta$-actin, however, no PCR product was seen for iNOS up to 32 cycles. We chose 29 cycles for all future RT-PCR reactions. nNOS was not assessed in this study, as previous studies have failed to show its presence in the liver $(4,5)$.

Maturational change in steady-state expression of eNOS RNA as determined by semiquantitative RT-PCR is shown in Figure $1 A$. A representative gel (Fig. $1 B$ ) shows a single PCR product for eNOS with the predicted size of $693 \mathrm{bp}$. Similarly, a single PCR product for $\beta$-actin was seen at the predicted size of $764 \mathrm{bp}$; this band was used to determine equal amplification.

Semiquantitation using densitometry showed that eNOS mRNA was present at low levels before delivery (gestational ages 18 and $20 \mathrm{~d}$ ) and on the day of birth. On d 1, eNOS

\section{A}
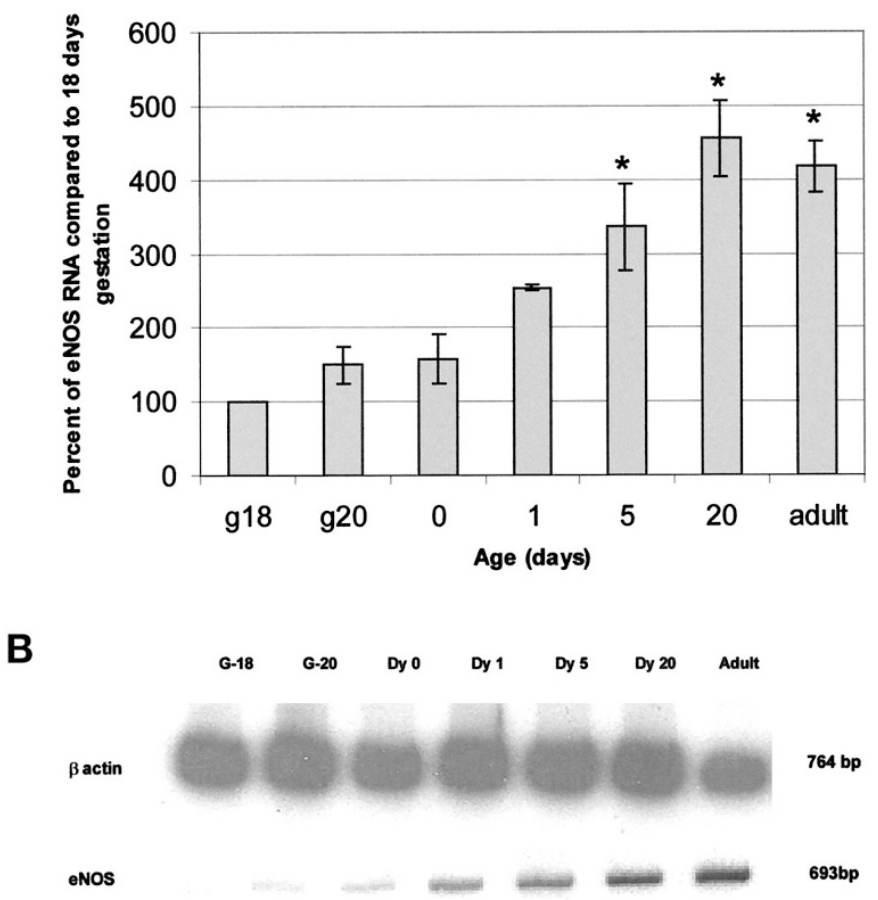

Figure 1. Developmental expression of eNOS RNA. (A) Semiquantitative densitometry of eNOS RNA was performed and standardized to $\beta$-actin. Values are depicted as means \pm SE expressed as a percentage of eNOS at $18 \mathrm{~d}$ gestation; $n=5-6$ for each time point; ${ }^{*} p<0.05$ compared with G18, G20, $\mathrm{d} 0$, and d 1. (B) Representative gel of RT-PCR products. $\beta$-actin was used to insure equal amplification. A single band was seen for each PCR product. 
mRNA was increased over preterm levels, however, it did not reach statistical significance. On d 5, there was a further increase in eNOS mRNA, which did reach statistical significance. Maximal expression of eNOS mRNA is seen on d 20; a 4.5 -fold increase compared with $18 \mathrm{~d}$ gestational age. The mRNA level remained relatively constant in the adult animal. Linear trend analysis revealed a significant $(p<0.001)$ increase in hepatic eNOS mRNA expression from preterm to adult.

eNOS protein expression. Maturational changes in eNOS protein expression in liver from fetal, neonatal, and adult rats are depicted in Figure $2 A$. The pattern of protein expression paralleled that of mRNA expression for eNOS. A representative Western blot is shown (Fig. 2B). Semiquantitative densitometry confirmed that eNOS protein is minimally expressed in the prenatal period and on the day of birth. On d 1 eNOS protein is significantly increased compared with earlier time points. There is a trend toward further increase on $\mathrm{d} 5$, however it does not reach statistical significance. Maximal expression of eNOS protein is seen on d 20 (6.9-fold increase compared with $18 \mathrm{~d}$ gestational age); the protein level remains relatively constant in the adult animal. Linear trend analysis revealed a significant $(p<0.001)$ increase in hepatic eNOS protein concentration from preterm to adult.

eNOS activity. The ontogeny of eNOS activity is depicted in Figure 3. The pattern of eNOS activity was similar to that of
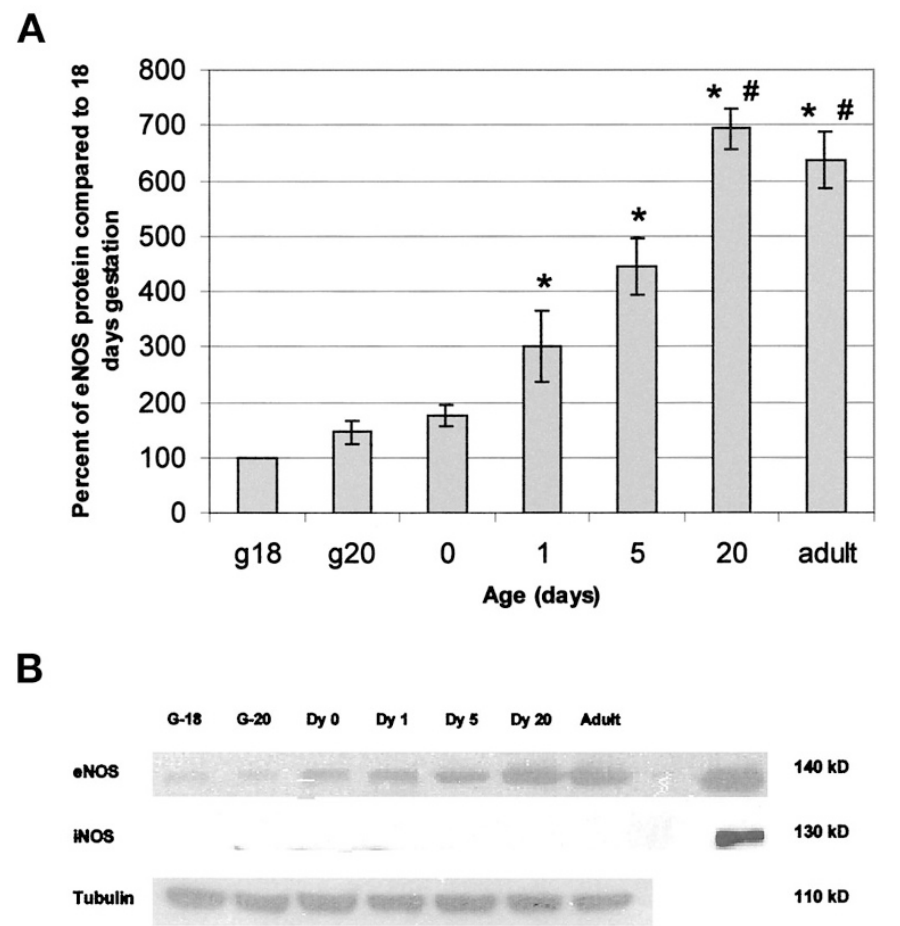

Figure 2. Developmental expression of eNOS and iNOS protein. (A) Semiquantitative densitometry of eNOS protein was performed and standardized to tubulin. Values are depicted as means $\pm \mathrm{SE}$ expressed as a percentage of eNOS at $18 \mathrm{~d}$ gestation; $n=5-6$ for each time point; ${ }^{*} p<0.05$ compared with G18, G20, and d 0; \#p $<0.05$ compared with $\mathrm{d} 1$ and 5. (B) Representative Western blot. The last lane contains purified eNOS $(0.9 \mu \mathrm{g})$ and iNOS $(8 \mu \mathrm{g})$ as positive controls. For detection of eNOS, $150 \mu \mathrm{g}$ of protein was loaded; for detection of iNOS, $300 \mu \mathrm{g}$ of protein was added. Tubulin was used as a marker for equal protein loading.

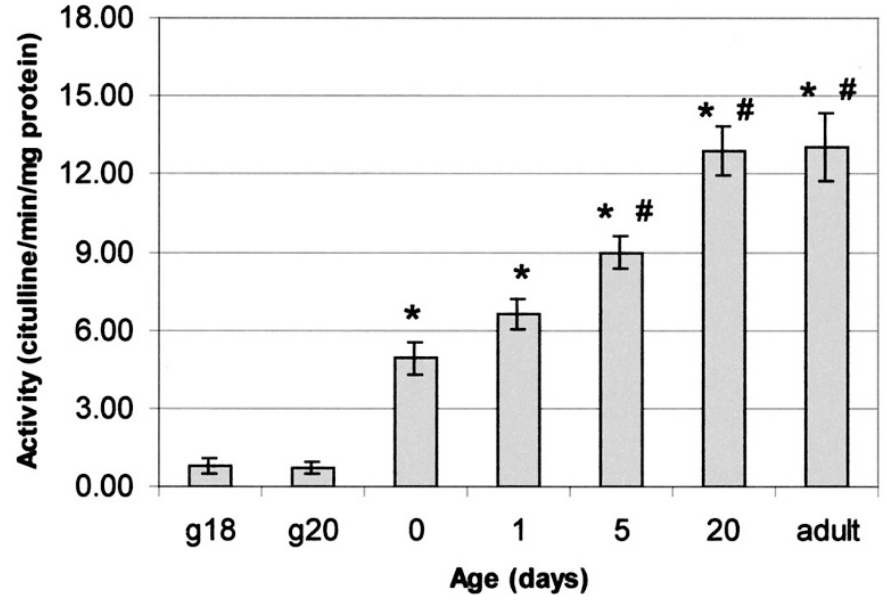

Figure 3. Developmental expression of eNOS activity. Values are expressed as means $\pm \mathrm{SE} ; n=5-6$ for each time point; ${ }^{*} p<0.05$ compared with G18, $\mathrm{G} 20 ; \# p<0.05$ compared with $\mathrm{d} 0$ and 1 .

mRNA and protein expression. Activity was present in low levels before birth. On the day of birth there is a significant increase in eNOS activity. Another significant increase in activity is seen on $\mathrm{d} 5$, which represents the time after closure of the ductus venosus. Maximal activity is seen on d 20 (16.1-fold increase compared with $18 \mathrm{~d}$ gestational age), which persisted unchanged in the adult. Linear trend analysis revealed a significant $(p<0.001)$ increase in hepatic eNOS activity from preterm to adult.

Expression of iNOS mRNA and protein. There was no identifiable iNOS mRNA in the liver at any age. Similarly, there was no detectable iNOS protein at any age. A representative Western blot is shown in Figure $2 B$.

Localization of eNOS by immunohistochemistry. Before birth there was marked staining for eNOS in areas of extramedullary hematopoiesis (Fig. 4B). At $18 \mathrm{~d}$ gestation there was no staining of endothelial cells, however, at $20 \mathrm{~d}$ gestation there was a hint of staining of central veins. After birth there was a gradual decrease in staining of extramedullary hematopoiesis and an increase in staining of the endothelium. On the day of birth staining was obvious in the central veins, with scattered staining of the sinusoids; there was no discernable change on $\mathrm{d}$ 1 (Fig. 4B). On d 5, staining was more pronounced in the central veins and portal vessels, with more diffuse staining of the sinusoids (Fig. 4B). On d 20, there was an increase in staining with nearly complete staining of the sinusoids (Fig. $4 B)$.

\section{DISCUSSION}

The present study determined the ontogeny of eNOS expression and activity in the rat liver. Increases in hepatic eNOS mRNA, protein level, and activity were seen from fetal to adult ages, with corresponding increase in immunostaining for eNOS in the sinusoids and central veins. eNOS was present before birth, albeit in low levels. After birth there was an increase in eNOS expression and activity, which reached a maximum at d 20 and persisted in the adult. Heretofore, developmental changes in hepatic eNOS have not been studied, 

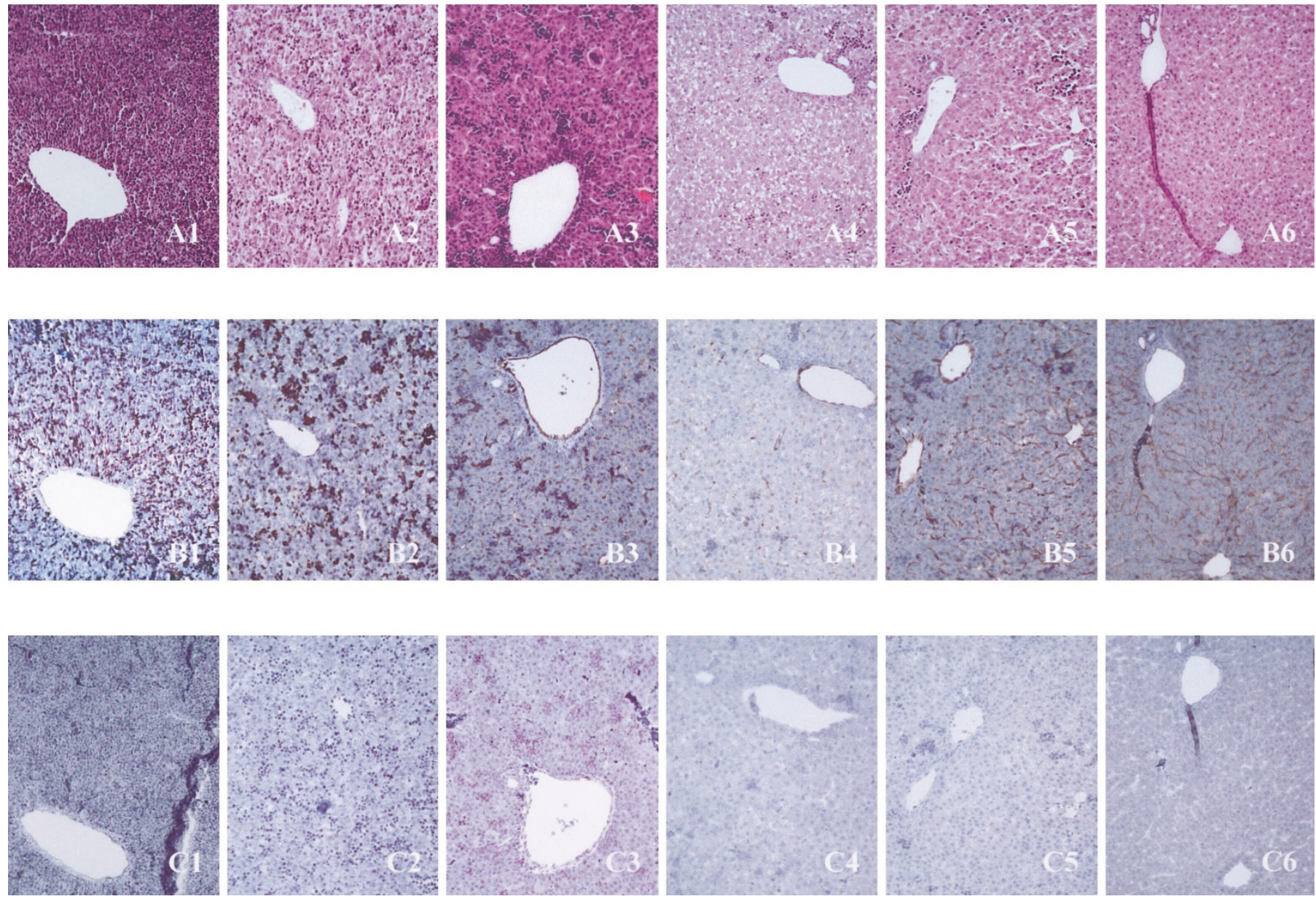

Figure 4. Immunohistochemistry of eNOS in the liver. Immunohistochemistry was performed on liver from various age rats to coincide with ages for determination of eNOS RNA, protein, and enzyme activity. For each time point one slide was stained with hemotoxylin and eosin (series $A$ ), one was stained for eNOS (series $B$ ), and one was a negative control for eNOS (series $C$ ). The number denotes the age as follows: $1=\mathrm{G} 18,2=\mathrm{G} 20,3=\mathrm{d} 0,4=\mathrm{d} 1,5=$ d $5,6=$ d 20 .

whereas there have been many studies addressing the changes in hepatic blood flow during the transition from fetal to neonatal circulation. Findings of the present study can be understood in relation to known changes in blood flow and oxygen delivery during the transition period.

Developmental changes in eNOS have been reported for other organs where blood flow changes significantly during the transition from fetal to extrauterine life. In point, the ductus arteriosus is regulated in part by eNOS. In oxygen tension mimicking that of the fetus, the ductus arteriosus can respond to exogenous NO despite being unable to produce it in vitro (7). However, once exposed to the elevated neonatal oxygen tension, the ductus arteriosus can produce NO (7). The vasodilatory effect of $\mathrm{NO}$ on the ductus arteriosus is more prominent in preterm animals than in the near-term animals, where prostaglandin $\mathrm{E}$ is the major vasodilator $(7,9)$.

In the developing lung, there is an increase in eNOS mRNA and protein in late gestation, reaching a maximal level at $20 \mathrm{~d}$ gestation, followed by a decrease in expression following birth (8). It has been proposed that maximizing pulmonary eNOS expression at birth may serve to optimize the capacity for NO-mediated pulmonary vasodilation during transition (17).
Similarly, there are major changes in hepatic blood flow with birth. In utero the liver is supplied by the hepatic artery, portal vein, and umbilical vein, the latter bringing oxygenated blood to the fetus. The ductus venosus serves to shunt this oxygenated blood to the heart, brain, head, and upper body. There is preferential shunting of blood from the ductus venosus to the left side of the heart through the foramen ovale. On average, about $50 \%$ of the umbilical vein blood is shunted through the ductus venosus (18); the percentage increases with fetal hypoxia (19). Local control of blood flow to the fetal liver may not be so crucial, as the placenta plays an important role in the metabolic homeostasis of the fetus. The fetus receives a continuous infusion of nutrients via placental blood flow that is high in carbohydrates and amino acids. In fact, hepatic gluconeogenesis does not occur at significant rates in the fetus, rather fetal glucose use during intrauterine life is about equal to umbilical vein glucose uptake (20). Similarly, in utero most amino acids are transported to the fetus by the placenta. At delivery the fetus becomes biochemically self-sufficient. As such, the liver must be able to perform all aspects of protein production, metabolic homeostasis, and detoxification, making control of hepatic blood flow important after birth. 
As previously mentioned, eNOS alone is expressed in the normal liver (12). Localization of eNOS is predominantly in the hepatic sinusoidal epithelium, primarily in the Golgi region of the cell (5). eNOS is important in regulating the basal vascular tone of the liver; expression of hepatic eNOS is influenced by hypoxia and shear forces $(4,5)$.

Our data show a 1.5-fold increase in both eNOS RNA and protein from gestational age $18 \mathrm{~d}$ to gestational age $20 \mathrm{~d}$, without any significant change in eNOS activity. On the day of birth there was no significant increase in either eNOS RNA or protein levels compared with preterm levels, but a 6-fold increase in eNOS activity. There are several possible explanations for the discrepancy between levels of RNA and protein and activity. It may be that, although the 1.5 -fold increases in RNA and protein levels were not statistically significant, they were biologically significant and accounted for the subsequent rise in eNOS activity.

Alternatively, there may be another factor that plays a role in the expression of eNOS activity at the time of delivery. A potential candidate is tetrahydrobiopterin (BH4), an essential cofactor for all three forms of NOS (21). The principal action of BH4 in intact endothelial cells is to increase the enzymatic activity of eNOS by stabilization of the enzyme, as well as to modestly increase the enzyme level (22). In the rat, the ratelimiting step in the biosynthesis of $\mathrm{BH} 4$ is under the control of the enzyme guanosine triphosphate (GTP) cyclohydrolase-I (23). There is variable developmental expression of both hepatic BH4 and GTP cyclohydrolase-I. In fetal mice at $20 \mathrm{~d}$ gestation, GTP cyclohydrolase-I is undetectable and BH4 is only $34 \%$ of adult levels, the latter presumably due to transplacental uptake from the maternal circulation (24). After birth there is seen a rapid rise in GTP cyclohydrolase-I activity and a concomitant increase in BH4 activity (24); findings that have been confirmed in other studies (25). In the context of our data, a postnatal rise in GTP cyclohydrolase-I and BH4 could stabilize the eNOS that is present and account for the significant rise in eNOS activity in the absence of a simultaneous rise in RNA and protein levels. Further rises in eNOS activity with age could be explained by increases in eNOS production, as well as further increases in BH4 activity.

Finally, the eNOS present before birth may not be biologically active. Insight into this concept can be gleaned from the localization of eNOS by immunohistochemistry. Before birth, eNOS is localized to areas of extramedullary hematopoiesis, a finding not previously reported. The potential role of eNOS in extramedullary hematopoiesis is discussed below. After delivery, eNOS is found in the endothelium of the sinusoids and central veins, where it can exert vasoactive properties.

The presence of immunoreactive eNOS in extramedullary hematopoiesis is quite interesting and raises several possible explanations. The presence of immunostaining may simply represent recognition of a protein homologous to eNOS. Alternately, it may represent eNOS that is immunoreactive but not physiologically active. An attractive hypothesis is that eNOS elaborated by extramedullary hematopoiesis serves to produce NO to support angiogenesis. Evidence supports that hematopoietic cells and endothelial cells originate from a common precursor (26). Endothelial cells, under stimulation by vascular endothelial growth factor, have an increased expression of eNOS and an increase in NO release (27). NO plays a role in angiogenesis, where it serves as an endothelial "survival factor"-inhibiting apoptosis, enhancing proliferation and migration of endothelial cells, and suppressing angiostatin (28, 29).

During transition in the immediate postgestational period there is a decrease in oxygen delivery to the liver (30). We contend that this relative hypoxia results in a further increase in eNOS expression. On d 1, eNOS mRNA, protein, and activity are increased 1.6-fold, 1.7-fold, and 1.3-fold, respectively, compared with the day of birth (d 0). Previous studies have shown that hepatic eNOS mRNA increases 2.0- and 2.6-fold in acute hypoxia induced by inhalation of $9 \%$ oxygen and $0.1 \%$ carbon monoxide, respectively (12). The response to acute hypoxia is not limited to the liver; increases in eNOS mRNA are seen in the right ventricle, lungs, and kidney, suggesting that the eNOS gene could be regulated by hypoxia (12). Similarly, eNOS mRNA and protein levels have been shown to increase in response to chronic hypoxia in the lung $(31,32)$.

Increases in eNOS expression occurring after $\mathrm{d} 1$ cannot be explained by hypoxia. However, the increased shear forces that accompany closure of the ductus venosus may directly lead to increased expression of eNOS. In a morphologic study in neonatal rats, the ductus venosus closed completely by $\mathrm{d} 2$ of life (33). With closure of the ductus venosus, the entirety of portal vein flow passes into the hepatic sinusoids. Although the liver is a low-resistance organ, there are increased shear forces associated with flow through the sinusoids (34). There is direct evidence that increased shear forces enhance eNOS activity (5, $35,36)$. The resulting increase in NO production from high shear forces can lead to vasodilation and subsequent decrease in resistance. In our study, maximal eNOS expression occurs after closure of the ductus venosus. There was a slight further increase on d 20, with no further change in the adult rat.

The lack of iNOS expression is in keeping with previous studies that failed to show the presence of iNOS in normal liver (32). However, we anticipated that iNOS would be detectable immediately after birth due to the relative hepatic hypoxia seen during this time period in accordance with previous studies have shown that ischemia-reperfusion leads to an increase in expression of hepatic iNOS (37). Absence of detectable iNOS expression immediately after birth may be explained by a relatively minor hypoxia that may result in a lesser stimulus than true ischemia reperfusion. Alternatively, our measures for iNOS mRNA, protein, and activity may not have been sensitive enough to allow detection.

We have shown that there is a developmental expression of eNOS in the liver, in keeping with similar findings in the vasculature of the heart and lungs. These results add to the understanding of physiologic changes in hepatic blood flow during the transition from fetal to extrauterine life. These data can serve as a baseline for further research to evaluate the effect various prenatal stressors (such as maternal hypertension, placental insufficiency, and hypoxia) on eNOS expression and hepatic blood flow in the fetal and neonatal rat. 
Acknowledgment. The authors thank Michael LeBlanc, M.D., for his critical reading of the manuscript and his many helpful suggestions.

\section{REFERENCES}

1. Geller DA, Lowenstein CJ, Shapiro RA, Nussler AK, Di Silvio M, Wang SC Nakayama DK, Simmons RL, Snyder SH, Billiar TR 1993 Molecular cloning and expression of inducible nitric oxide synthase from human hepatocytes. Proc Natl Acad Sci U S A 90:3491-3495

2. Helyar L, Bundschuh DS, Laskin JD, Laskin DL 1994 Induction of hepatic Ito cell nitric oxide production after acute endotoxemia. Hepatology 20:1509-1515

3. Rockey DC, Chung JJ 1996 Regulation of inducible nitric oxide synthase in hepatic sinusoidal endothelial cells. Am J Physiol 271:G260-G267

4. Mittal MK, Gupta TK, Lee FY, Sieber CC, Groszmann RJ 1994 Nitric oxide modulates hepatic vascular tone in normal rat liver. Am J Physiol 267:G416-G422

5. Shah V, Haddad FG, Garcia-Cardena G, Frangos JA, Mennone A, Groszmann RJ, Sessa WC 1997 Liver sinusoidal endothelial cells are responsible for nitric oxide modulation of resistance in the hepatic sinusoids. J Clin Invest 100:2923-2930

6. Ignarro LJ 1989 Endothelium-derived nitric oxide: actions and properties. FASEB J 3:31-36

7. Clyman RI, Waleh N, Black SM, Riemer K, Mauray F, Chen YQ 1998 Regulation of ductus arteriosus patency by nitric oxide in fetal lambs: the role of gestation, oxygen tension, and vasa vasorum. Pediatr Res 43:633-644

8. North AJ, Star RA, Brannon TS, Ujiie K, Wells LB, Lowenstein CJ, Snyder SH, Shaul PW 1994 Nitric oxide synthase type I and type III gene expression are developmentally regulated in rat lung. Am J Physiol 266:L635-L641

9. Momma K, Toyono M 1999 The role of nitric oxide in dilating the fetal ductus arteriosus in rats. Pediatr Res 46:311-315

10. Botti JJ, Edelstone DI, Caritis SN, Mueller-Heubach E 1982 Portal venous blood flow distribution to liver and ductus venosus in newborn lambs. J Obstet Gynecol 144:303-308

11. Zink J, Van Petten GR 1980 Time course of closure of the ductus venosus in the newborn lamb. Pediatr Res 14:1-3

12. Gess B, Schricker K, Pfeifer M, Kurtz A 1997 Acute hypoxia upregulates NOS gene expression in rats. Am J Physiol 273:R905-R910

13. Cai Z, Hutchins JB, Rhodes PG 1998 Intrauterine hypoxia-ischemia alters nitric oxide synthase expression and activity in fetal and neonatal rat brains. Dev Brain Res 109:265-269

14. Cai Z, Xiao F, Lee B, Paul IA, Rhodes PG 1999 Prenatal hypoxia-ischemia alters expression and activity of nitric oxide synthase in the young rat brain and causes learning deficits. Brain Res Bull 49:359-365

15. Miralles C, Busquets X, Santos C, Togores B, Hussain S, Rahman I, MacNee W, Agusti AG 2000 Regulation of iNOS expression and glutathione levels in rat liver by oxygen tension. FEBS Lett 476:253-257

16. Bredt DS, Snyder SH 1990 Isolation of nitric oxide synthetase, a calmodulinrequiring enzyme. Proc Natl Acad Sci U S A 7:682-685

17. Shaul PW 1997 Ontogeny of nitric oxide in the pulmonary vasculature. Semin Perinatol 21:381-392
18. Rudolph AM, Heymann MA 1970 Circulatory changes with growth in the fetal lamb. Circ Res 26:289-299

19. Reuss ML, Rudolph AM 1980 Distribution and recirculation of umbilical and systemic venous blood flow in fetal lambs during hypoxia. J Dev Physiol 2:71-84

20. Hay Jr WW, Sparks JW, Wilkening RB, Battaglia FC, Meschia G 1984 Fetal glucose uptake and utilization as functions of maternal glucose concentration. Am J Physiol 246:E237-E242

21. Cosentino F, Luscher TF 1999 Tetrahydrobiopterin and endothelial nitric oxide synthase activity. Cardiovasc Res 43:274-278

22. Cai S, Alp NJ, McDonald D, Smith I, Kay J, Canevari L, Heales S, Channon KM 2002 GTP cyclohydrolase I gene transfer augments intracellular tetrahydrobiopterin in human endothelial cells: effects on nitric oxide synthase activity, protein levels and dimerisation. Cardiovasc Res 55:838-849

23. Blau N, Niederwieser A 1985 GTP-cyclohydrolases: a review. J Clin Chem Clin Biochem 23:169-176

24. Hoshiga M, Hatakeyama K, Watanabe M, Shimada M, Kagamiyama H 1993 Autoradiographic distribution of $\left[{ }^{14} \mathrm{C}\right]$ tetrahydrobiopterin and its developmental change in mice. J Pharmacol Exp Ther 267:971-978

25. Yoshida YI, Eda S, Masada M 2000 Alterations of tetrahydrobiopterin biosynthesis and pteridine levels in mouse tissues during growth and aging. Brain Dev 22:S45-S49

26. Wagner RC 1980 Endothelial cell embryology and growth. Adv Microcirc 9:45-75

27. Hood JD, Meininger CJ, Ziche M, Granger HJ 1998 VEGF upregulates ecNOS message, protein, and NO production in human endothelial cells. Am J Physiol 274(3 Pt 2):H1054-H1058

28. Murohara T, Witzenbichler B, Spyridopoulos I, Asahara T, Ding B, Sullivan A, Losordo DW, Isner JM 1999 Role of endothelial nitric oxide synthase in endothelial cell migration. Arterioscler Thromb Vasc Biol 19:1156-1161

29. Dimmeler S, Hermann C, Galle J, Zeiher AM 1999 Upregulation of superoxide dismutase and nitric oxide synthase mediates the apoptosis-suppressive effects of shear stress on endothelial cells. Arterioscler Thromb Vasc Biol 19:656-664

30. Townsend SF, Rudolph CD, Rudolph AM 1989 Changes in ovine hepatic circulation and oxygen consumption at birth. Pediatr Res 25:300-304

31. Le Cras TD, Xue C, Rengasamy A, Johns RA 1996 Chronic hypoxia upregulates endothelial and inducible NO synthase gene and protein expression in rat lung. Am J Physiol 270:L164-L170

32. Li D, Laubach VE, Johns RA 2001 Up-regulation of lung soluble guanylate cyclase during chronic hypoxia is prevented by deletion of eNOS. Am J Physiol 281:L369L376

33. Momma K, Ito T, Ando M 1992 In situ morphology of the ductus venosus and related vessels in the fetal and neonatal rat. Pediatr Res 32:386-389

34. Lipowsky HH, Kovalcheck S, Zweifach BW 1978 The distribution of blood rheological parameters in the microvasculature of cat mesentery. Circ Res 43:738-749

35. Kuchan M, Jo H, Frangos J 1994 Role of G proteins in shear stress-mediated nitric oxide production by endothelial cells. Am J Physiol 267:C753-C758

36. Uematsu M, Ohara Y, Navas J, Nishida K, Murphy TJ, Alexander RW, Nerem RM, Harrison DG 1995 Regulation of endothelial cell nitric oxide synthase mRNA expression by shear stress. Am J Physiol 269:C1371-C1378

37. Hur GM, Ryu YS, Yun HY, Jeon BH, Kim YM, Seok JH, Lee JH 1999 Hepatic ischemia/reperfusion in rats induces iNOS gene transcription by activation of NF- $\kappa$ B Biochem Biophys Res Commun 261:917-922 